\title{
Expression of parathyroid hormone related peptide in human pituitary tumours
}

\author{
M Ito, H Enomoto, T Usa, M C Villadolid, A Ohtsuru, H Namba, I Sekine, S Yamashita
}

\begin{abstract}
The presence of parathyroid hormone related peptide (PTHrP) was studied in 20 patients with pituitary adenomas and one patient with pituitary adenocarcinoma. PTHrP expression was shown in almost all of the pituitary adenomas $(95 \%)$ and in $100 \%(n=7)$ growth hormone producing pituitary adenomas. A metastatic lesion from a pituitary growth hormone producing adenocarcinoma revealed strongly expressed PTHrP. It was weakly detected in normal pituitary cells in all of the specimens $(n=10)$. There was no significant correlation, however, between PTHrP expression and the clinical or pathological features of growth hormone producing tumours. Apart from an important role in the physiological function of the pituitary gland, PTHrP may be closely related to somatotroph tumorigenicity.
\end{abstract}

$(\mathcal{C}$ Clin Pathol 1993;48:682-683)

Various growth factors occur in the human pituitary gland. ${ }^{1}$ These growth factors may be involved in the gland's endocrine function regardless of whether they are actually produced by pituitary cells. Parathyroid hormone related peptide (PTHrP) was originally isolated from human tumour cells derived from patients with hypercalcaemia of malignancy, ${ }^{23}$ but the PTHrP gene is widely expressed in normal and neoplastic tissues and functions in a paracrine and an autocrine manner. ${ }^{4}$ Recently our preliminary data have demonstrated the presence of PTHrP mRNA in rat pituitary glands and in rat $\mathrm{GH}_{3}$ pituitary tumour cells. We therefore extended our study to human pituitary tissues to investigate the presence of PTHrP and analyse the association between pituitary gland cell types and positive PTHrP immunostaining.

Department of Pathology, Atomic Nagasaki University School of Medicine, 1-12-4 Sakamoto, Nagasaki 852, Japan $M$ Ito I Sekine

Department of Cell Physiology $\mathrm{H}$ Enomoto T Usa

M C Villadolid

A Ohtsuru

H Namba

S Yamashita

Correspondence to: Dr Shunichi Yamashita Accepted for publication 27 January 1993 to $4 \mu \mathrm{m}$, dewaxed in xylene, and rehydrated in phosphate buffered saline. Dewaxed sections were preincubated with normal bovine serum to prevent non-specific binding, and then incubated with an optimal dilution $(5 \mu \mathrm{g} / \mathrm{ml})$ of the primary antibody of human PTHrP (Oncogene Science, Uniondale, New
York, USA) overnight at $4^{\circ} \mathrm{C}$. The slides were sequentially incubated with alkaline phosphatase conjugated goat anti-mouse immunoglobulin antibodies. The alkaline phosphatase reaction was demonstrated using a BCIP/NBT (BRL, Gaithersburg, Maryland). In all cases, Copenhagen immunohistochemical staining of growth hormone, prolactin, adrenocorticotropic hormone, thyroid stimulating and follicular stimulating hormone (Dakopatts (ABC)) was performed in serial sections using the avidin-biotin-peroxidase complex method with diaminobenzidine as the chromogenic substrate (Vectastain Elite kits, Burlingham, California), after exposure to a $0.3 \%$ solution of hydrogen peroxide in absolute methanol to block endogenous peroxidase. Cultured cells producing PTHrP (human squamous cell carcinoma cell line) served as internal positive controls in immunostaining for PTHrP. Negative controls were prepared by replacing the primary antibody with non-immune serum.

\section{Results}

PTHrP expression was occasionally seen in the anterior lobe of pituitary glands in all normal cases $(n=10)$. Among the variable endocrine cells, the immunoreactivity to PTHrP was relatively stronger in the cells secreting growth hormone by serial immunodetection (figs 1A and B). We found PTHrP immunoreactivity in all human pituitary tumours producing growth hormone. A metastatic lesion in the spinal cord from a pituitary adenocarcinoma strongly expressed PTHrP, suggesting growth hormone producing cells confirmed by both anti-growth hormone and anti-PTHrP antibody, respectively (figs 1C, D). Most pituitary adenomas stained for PTHrP, but the degree of postivity was different for each cell type. Primary and secondary cell adenomas were densely positive for PTHrP. Immunohistochemical staining results are summarised in the table. In prolactin producing adenomas and null cell adenomas, a weakly positive immunoreaction was usually observed. Somatotrophic characteristics may feature in PTHrP positivity in prolactin cell adenomas. There was no significant correlation between PTHrP expression and clinical features, such as patient age or sex, or morphological features, such as tumour size.

\section{Discussion}

That PTHrP is present in normal human pituitary glands has been proved in this study, 


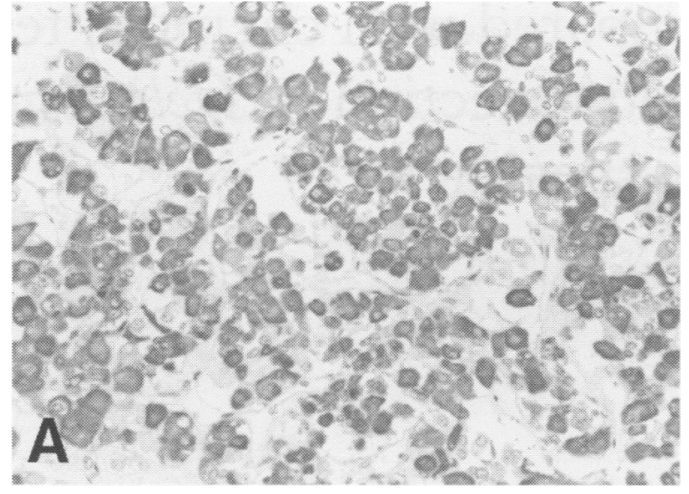

(A) Most cells in normal pituitary glands comprise growth hormone cells ( $A B C$ method).

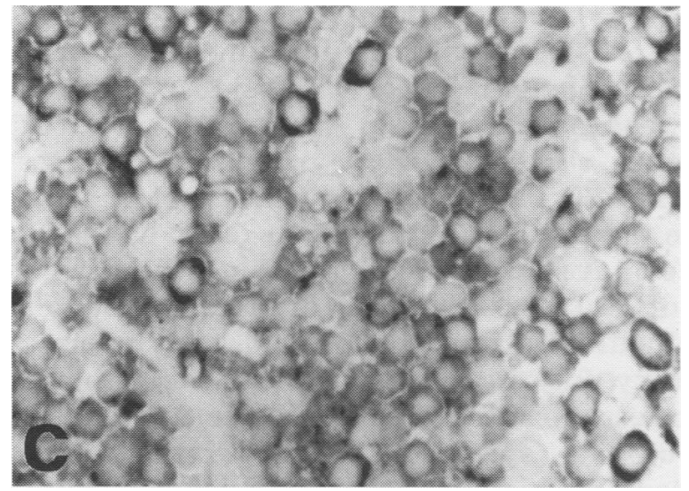

(C) The metastatic growth hormone producing tumour cells exhibit varying degrees of positivity for growth hormone ( $A B C$ method).

suggesting the co-localisation of growth hormone and PTHrP in the same mammosomatotroph cell. This was supported by evidence of strong positivity of PTHrP in growth hormone producing pituitary tumours. There was only one case of invasive growth hormone producing adenocarcinoma, ${ }^{5}$ and the strongest positivity of PTHrP staining in this metastatic tumour suggests that a worsening prognosis and metastatic activity of somatotroph tumours are closely related to the induction of PTHrP gene by a mechanism similar to that of other PTHrP producing tumours. ${ }^{67}$ Northern blot analysis in human growth hormone producing pituitary tumours also confirmed the presence of multiple forms of PTHrP mRNA species (unpublished data). Furthermore, the human pituitary, especially the somatotroph cell, is known to secrete PTHrP in the local circulation to regulate pituitary function physiologically. Parathyroid hormone itself is a well known growth factor for pituitary tumour cell growth in rats, ${ }^{8}$ suggesting that PTHrP functions in the pituitary through a common parathyroid hormone PTHrP receptor. The presence of PTHrP

Cell type and PTHrP immunoreactivity (No/\%) in human pituitary adenomas

\begin{tabular}{lrcll}
\hline & \multicolumn{3}{c}{ PTHrP expression } \\
\cline { 5 - 5 } Cell type & $n$ & Strongly positive & Weakly positive & Negative \\
\hline Growth hormone cell adenoma & 7 & $7 / 7(100)$ & & \\
Prolactin cell adenoma & 6 & $1 / 6(16 \cdot 7)$ & $4 / 6(66 \cdot 7)$ & $1 / 6(16 \cdot 7)$ \\
Null cell adenoma & 7 & $2 / 7(28 \cdot 6)$ & $5 / 7(71 \cdot 4)$ & $1 / 20(5)$ \\
Total & 20 & $10 / 20(50)$ & $9 / 20(45)$ & \\
\hline
\end{tabular}

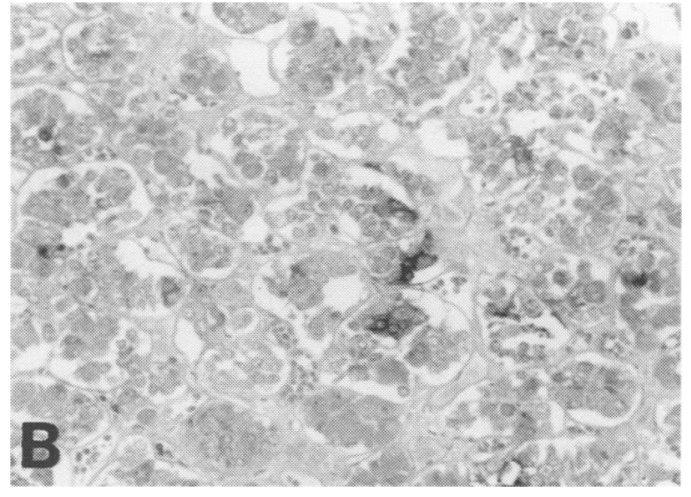

(B) PTHrP immunoreactive cells are occasionally present in the anterior lobe; these are especially clearly positive in the area of growth hormone positive cell clusters corresponding to fig $A$ (immunoalkaline phosphatase method).

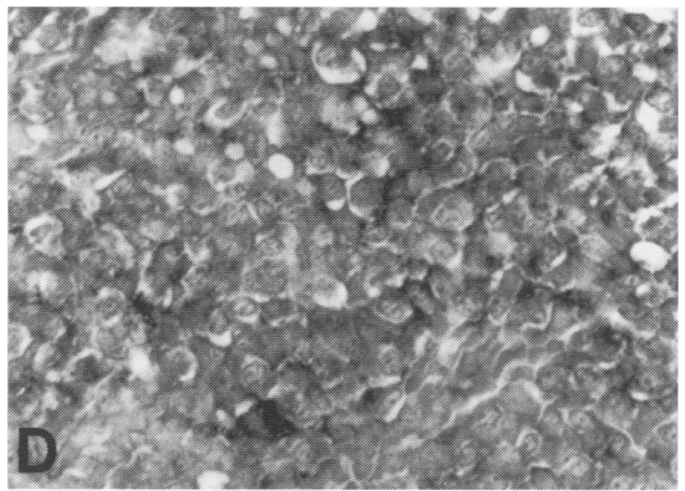

(D) Most of the tumour cells are strongly positive for PTHrP corresponding to fig $C$ (immunoalkaline phosphatase method).

mRNA in rat pituitary $\mathrm{GH}_{4}$ tumour cells has already been shown. ${ }^{9}$ The paracrine/ autocine role of PTHrP in normal pituitary function, however, remains to be evaluated. At present there is no single accurate predictor which can identify acromegalic patients with pituitary growth hormone producing tumours at risk of developing malignant changes and metastatic spread. ${ }^{10}$ In general, acromegalic patients are not hypercalcaemic, but the measurement of PTHrP in cerebrospinal fluid might help to evaluate the grade of malignancy of these tumours.

1 Halper J, Parnell PG, Carter BJ, Ren P, Scheithauer BW. Presence of growth factors in human pituitary. Lab Invest 1992;66:639-45.

2 Strewler GJ, Stern PH, Jacobs JW, et al. Parathyroid hormone like protein from human renal carcinoma cells. $f$ Clin Invest 1987;80:1803-7.

3 Moseley JM, Kubota M, Dieffenbach-Jagger H, et al. Parathyroid hormone related protein purified from human lung cancer cell line. Proc Natl Acad Sci USA 1987;84:5048-52.

4 Orloff J, Wu TL, Stewart AF. Parathyroid hormone-like proteins: biochemical responses and receptor interactions. Endocrinol Rev 1989;10:476-95.

5 Yamashita S, Izumi M, Nagataki S. Acromegaly and pituitary carcinoma. Ann Intern Med 1992;117:1057-8.

6 Martin TJ, Moseley JM, Gillespie MT. Parathyroid hormone-related protein: biochemistry and molecular hormone-related protein: biochemistry and molecular

7 Vargas SJ, Gillespie MT, Powell GJ, et al. Localization of parathyroid hormone-related protein mRNA expression parathyroid hormone-related protein mRNA expression in breast cancer and metastatic lesions by

8 Tashjian A Jr. Clonal strains of hormone-producing pituitary cells. Methods Enzymol 1979;58:527-35.

9 Ikeda K, Weir EC, Mangin M, et al. Expression of messenger ribonucleic acids encoding a parathyroid hormone-like peptide in normal human and animal tissues with abnormal expression in human parathyroid adenomas. Mol Endocrinol 1988;2:1230-6.

10 Melmed S. Acromegaly. N Engl f Med 1990;322:966-77. 